\title{
Pathogen-free PTI induction with a plant conditioner
}

\author{
Kincső Decsi ${ }^{1}$ - Barbara Kutasy ${ }^{1}$ - Márta Kiniczky³ - Géza Hegedüs ${ }^{2}$ - Zoltán Péter Alföldi ${ }^{4}$ - Nikoletta Kálmán ${ }^{5}$ - \\ Ágnes $\mathrm{Nagy}^{3}$ - Zsófia Thomas-Nyári ${ }^{3}$ and Eszter Virág ${ }^{3,2,6}$
}

${ }^{1}$ Department of Plant Physiology and Plant Ecology, Campus Keszthely, Hungarian University of Agriculture and Life Sciences Georgikon, Keszthely, Hungary, szaszkone.decsi.eva.kincso@uni-mate.hu, kutasy.barbara.julia@uni-mate.hu

2 EduCoMat Ltd. Keszthely, Hungary, hegedus@educomat.hu

${ }^{3}$ Research Institute for Medicinal Plants and Herbs Ltd. Budakalász, Hungary, kiniczky.m@gynki.hu, aginagy.nagy@gmail.com, thomas.nyari.zs@gynki.hu

${ }^{4}$ Department of Environmental Biology, Campus Keszthely, Hungarian University of Agriculture and Life Sciences Georgikon, Keszthely, Hungary, alfoldi.zoltan.peter@uni-mate.hu

${ }^{5}$ Department of Biochemistry and Medical Chemistry, University of Pecs, Medical School, Pecs, Hungary, knikoletta@gmail.com

${ }^{6}$ Department of Molecular Biotechnology and Microbiology, Institute of Biotechnology, Faculty of Science and Technology, University of Debrecen, Egyetem Square 1, Hungary, 4032,

*Corresponding author: eszterandreavirag@gmail.com

\begin{abstract}
The effects of ELICE16INDURES, a well-known plant conditioner developed by the Research Institute for Medicinal Plants and Herbs Ltd. Budakalasz, Hungary, were studied in a soybean population. The active ingredients of the compound have been selected to help elicit general immunity in plants without pathogenic damage, thereby roborizing the healthy plant population and preparing it for possible future biotic stressors. Here we have analyzed changes in the expression levels of genes encoding enzymes involved in the catalysis of metabolic pathways that induce and regulate PAMP-triggered immunity (PTI) at two different time points and treatments. Twenty-three different enzymes were analyzed that catalyze different metabolic pathways, such as the biosyntheses of jasmonic acid, salicylic acid, ethylene, phenylpropanoid, flavonoid, and phytoalexin biosynthesis and cellular detoxification processes. Bioinformatical softwares werw used to analyze the results. It has been found that some of the primary defense mechanisms (e.g., Mitogen-Activated-Protein Kinase (MAPK) cascade, jasmonic acid biosynthesis, flavonoid and phytoalexin biosynthesis, etc.) that intensify following the attack of pathogens can be activated without the intrusion of the actual pathogen by an immunochemical. Thus, we proved that plant resistance can be artificially conditioned.
\end{abstract}

Keywords: PAMP-triggered immunity; priming; transcriptomical analysis

\section{Treatment of Glycine max}

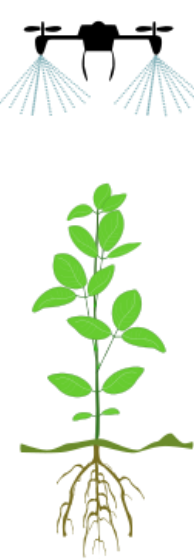

First exposure:

Treated by biostimulant

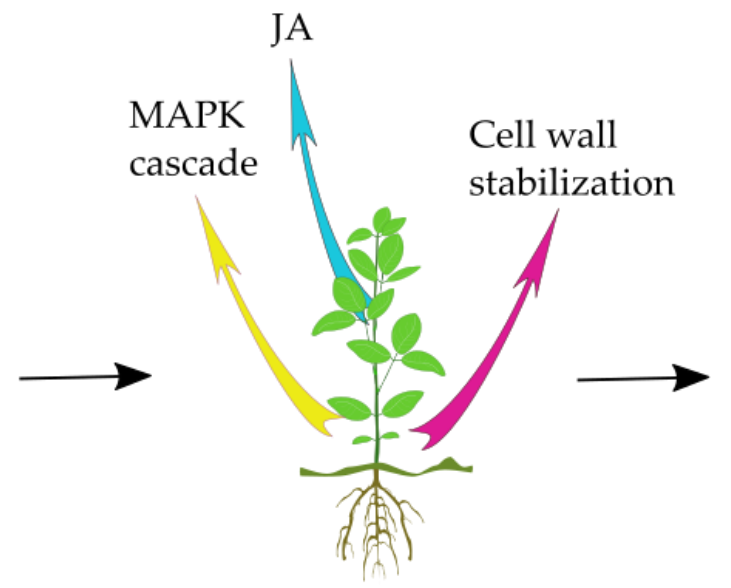

Primed soybean

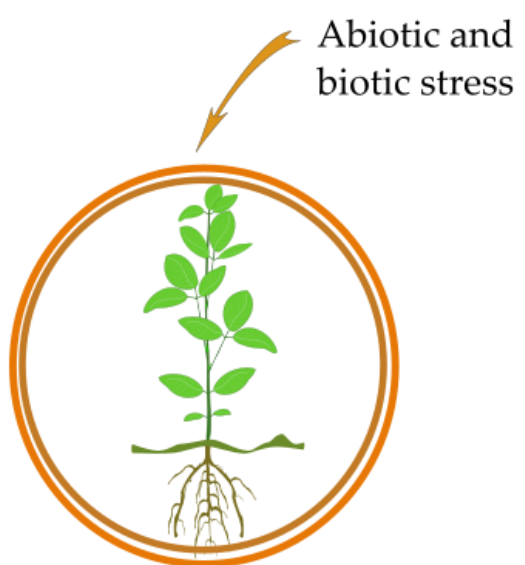

Second exposure:

Enhanced defense

\section{Introduction}


The essence of both the plant and animal immune systems is to be able to distinguish between their own and foreign substances and cells (viruses, bacteria, fungi, etc.) and to neutralize the extraneous after recognition. In all cases where this recognition is delayed or missed, a severe form of the disease occurs. In plants, similarly to the animal immune system, two types of defense systems can be distinguished: (1) general (inherent) resistance, which corresponds to natural (innate) immunity in the animal kingdom; (2) the specific (hypersensitive) resistance (HR), which can be considered analogous to the adaptive (acquired) immune system in the animal kingdom [1]. It is common for plants that each plant cell defends itself, performing both general and specific defenses on its own.

The mechanisms for the development of active, inducible plant responses are based on the plant's recognition of elicitor compounds produced by the pathogen. Elicitors are molecules, produced by microbes or derived from the surface of microbes, that are capable of eliciting a plant response. There are many similarities at the molecular level between the plant disease resistance response and the innate immunity of mammals. In animal and plant organisms, innate immune responses are mediated by special molecules, Pathogen-Associated Molecular Patterns (PAMPs) on the surface of the pathogen [2]. The ability of the host to recognize these patterns and elicit an immune response results in broadspectrum resistance to pathogens [3]. PAMPs bind to recognition receptors and elicit an immune response that initiates gene expressions which are followed by the production of antimicrobial compounds. Since PAMPs have a highly conserved structure, the responses they induce are also found in the plant kingdom [4], which are called as inherent or general immunity. PAMP-induced defense reactions and associated biochemical pathways have been widely studied for long [5-7]. The finding that PAMP-induced immunity (PTI) is an ancient form of innate immunity has also been confirmed repeatedly $[8,9]$.

Inducible defense is likely consist of a series of complex and interrelated stress responses that can be triggered by other stimuli in addition to microbial attacks [10]. The activation of plant innate immunity starts in the infected part, and then information is passed through signaling pathways to uninfected tissues, providing long-term resistance to a wide range of pathogens. This immunity is called systemic acquired immunity (SAR) [11]. Induced systemic resistance (ISR) is a form of systemic immunity [12] that is usually triggered by non-pathogenic microbes. ISR-conditioned plants may elicit faster and/or stronger protection during subsequent pathogenic interactions, and this sensitization mechanism is called priming [13].

The priming reaction can also be triggered by artificial chemicals, such as, for example, artificial salicylic acid (SA) derivatives. These substances were successfully applied in cucumber against several fungal pathogens [14]. This chemical group includes isonicotinic acid (INA) and its derivatives [15-18]; thiadiazole and isothiadiazole derivatives (BTH) [19-21]; and synthetic jasmonic acid (JA) [22-25]. In addition to the above compounds, benzoylsalicylic acid (BzSA) [26]; and $\beta$-aminobutyric acid (BABA) [27] have also been used successfully.

Following the previous idea, the aim of our study was to investigate the inducible defense processes in plants under non-pathogen-induced conditions. For this purpose, we used the immunochemical ELICE16INDURES, an immunostimulant consisting of natural ingredients developed by the Research Institute for Medicinal Plants and Herbs Ltd. Budakalasz, Hungary [28], which was tested in two doses in the field in a soybean population. Although soybean is an economically important crop exposed to a wide range of biotic stressors, the priming reactions induced by natural immunochemicals is not yet known. We investigated the activation of biochemical pathways involved in PTI - which are normally induced in response to microbial attack - after applying this immunochemical. During the experiment, we provided adequate plant protection, thus preventing the attack of pathogens.

\section{Results and discussions}

Genes encoding enzymes involved in the catalysis of metabolic pathways inducing and regulating pathogeninduced plant immunity (PAMP) were examined in a soybean population at two different times in three treatments. Twenty-five different enzymes were tested that catalyze different metabolic pathways, such as the biosyntheses of JA, SA, ethylenes (ET), phenylpropanoids, flavonoids, phytoalexins, and cellular detoxification. Congenital or general immunity, although externally asymptomatic in effect, induces a number of additional cellular processes (Fig.1). 


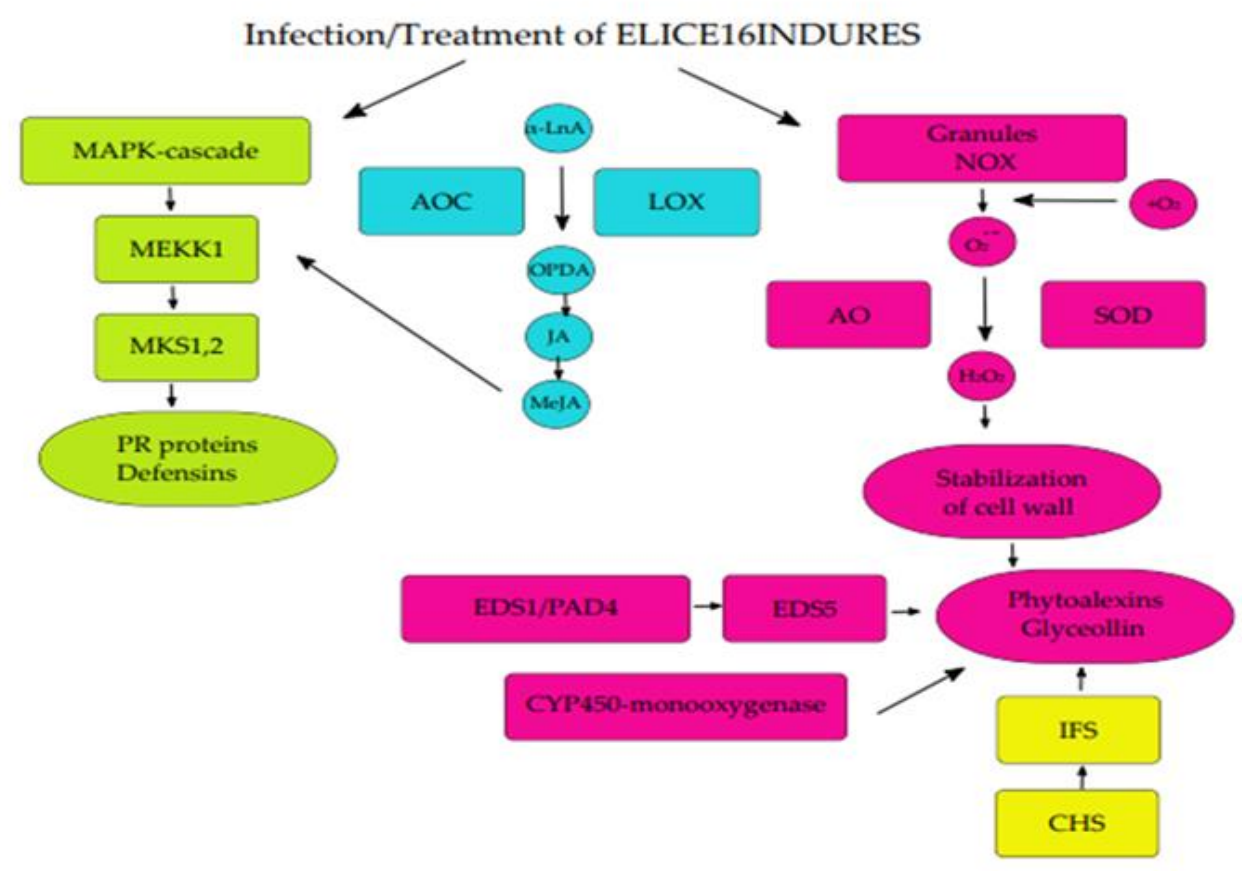

Figure 1.: Enzymes and biochemical pathways induced by ELICE16INDURES plant conditioner treatments (Abbreviations: MAPK: mitogen-activated protein kinase, MEKK1: MAPK/ERK kinase kinase, MKS1,2: Meckel syndrome type 1 protein, PR: pathogenesis-related protein, $\alpha$-LnA: locked nucleic acid with alpha-D-configuration, AOC: allene-oxide cyclase, LOX: lipoxygenase enzyme, OPDA: 12-oxo-phytodienoic acid, JA: jasmonic acid, MeJA: methyl jasmonate, NOX: NADPH oxidase, AO: aldehyde oxidase, SOD: superoxide dismutase, EDS1/PAD4: enhanced disease susceptibility1 and its co-regulator phytoalexin deficient4, EDS5: enhanced disease susceptibility5, CYP450: cytochrome P450, IFS: isoflavonoid synthase, CHS: chalcone synthase).

In the population treated by lower dose of plant conditioner after the first treatment 966,199 of 9,919,253 reads were assembled to 23 reference sequences and produced 23 contigs.

A clear increase in the expression level of mitogen-activated protein kinase cascade (MAPK cascade) enzymes was observed at the first sampling time in this study, as the result of the lower dose treatment (Fig. 2). This elevated levels of the cascades enzymes are the first indication of the immunostimulatory effect of ELICE16INDURES. Plants protect themselves against stresses by recognizing and transmitting signals inside the cell via signaling pathways such as the MAPK pathway [29]. Cell surface receptors immediately send a message to the nucleus about the presence of a virulent microorganism. This intracellular messaging occurs through MAPK cascades. MAPK is activated by various biotic and abiotic stresses and is regulated by the upstream regulator MAPK kinase (MAPKK), which in turn is regulated by MAPKK kinase (MAPKKK). This modulation is conserved in all eukaryotes.

A few studies have been conducted on plants to investigate MAPK translocations [30] in parsley; [31] in Arabidopsis; and [32] in soybean. Different abiotic stresses induce a number of cascades [33, 34]. Plant defense responses also include the synthesis of pathogen-related proteins and phytoalexins. MAPKs have been shown to play a central role in pathogen defense in Arabidopsis [35, 36], tobacco [37], tomato [38], parsley [39], brassica [40] and rice [41].

As a result of the attack of some infectious agents, the thickening of the plant cell wall is primarily observed as a typical stress response [42]. This thickening is caused by the deposition of silica and callose in the cell wall. When microbes attack the plant, a polymer of callose is formed and deposited at a high rate in the space between the cell wall and the cell membrane. This helps to concentrate antimicrobial compounds (e.g., phytoalexins, ROS, etc.) in the plant at the site of the pathogen entry and also acts as a physical barrier. In the part of the plant cell in contact with the pathogen, locally, vesicles, small spheres and granules form from the cytoplasm. From the material released from these granules, papillae rich in phenols and callose are formed, which are located in the space between the cell membrane and the solid cell wall. Simultaneously, cell wall thickening and a gradual membrane surrounding the pathogen develop, leading to immobilization and death of the infected cell [43]. An important component of the granules is the enzyme NADPH oxidase (NOX), which produces superoxide anions $\left(\mathrm{O}^{\bullet} \cdot\right)$ using oxygen. The resulting superoxide anion is then converted to hydrogen peroxide $\left(\mathrm{H}_{2} \mathrm{O}_{2}\right)$ by the enzyme superoxide dismutase (SOD), and $\mathrm{H}_{2} \mathrm{O}_{2}$ induces 
the formation of crosslinks between cell wall proteins. This makes the cell wall proteins insoluble, which strengthens the cell wall. This rapid reaction precedes the transcription of genes involved in defense [44, 45].

In our experiment, the level of the enzyme amine oxidase (AO), which catalyzes the synthesis of locally produced $\mathrm{H}_{2} \mathrm{O}_{2}$ in different cellular organs, was also increased. Recent research has supported the involvement of enzymes of the AO protein family in the synthesis of $\mathrm{H}_{2} \mathrm{O}_{2}$, which is formed separately in different cellular organs, and $\mathrm{H}_{2} \mathrm{O}_{2}$ is probably play a key role in preventing biotic stressor-induced infection [46]. This is accompanied by an increase in the expression of the genes of ascorbate peroxidase (APX) enzyme, which indirectly indicates an increase in the amount of $\mathrm{H}_{2} \mathrm{O}_{2}$, a compound that plays a primary role in stabilizing cell walls. Egbichi et al. (2014) [47] measured increased level of $\mathrm{H}_{2} \mathrm{O}_{2}$ followed by an increase in APX levels in soybeans induced by nitric oxide applied externally. As a result, increased antioxidant synthesis and tolerance to abiotic stress were demonstrated. Accumulated and excess $\mathrm{H}_{2} \mathrm{O}_{2}$ is neutralized and converted to water by the enzyme APXs or catalase (CAT). One of the key enzymes in the Halliwell-Asada cycle is APX, and since there is no CAT production in chloroplasts, the $\mathrm{H}_{2} \mathrm{O}_{2}$ generated here is neutralized by this cycle [48].

Treatment with ELICE16INDURES also increases the levels of the enzyme cytochrome P450 monooxygenase (CYP), which is known to be a catalyst for phytoalexin production after cell wall thickening. The gene expression changes of the CYP enzyme family and their effects were examined in soybean [49]. The cytochrome P450 (CYP; P450s) superfamily is the largest family of enzymatic proteins in plants and other organisms. P450s protect the plants from various biotic and abiotic stressors. Cytochrome P450 monooxygenases (P450s) catalyze the oxidation of various substrates using oxygen and $\mathrm{NAD}(\mathrm{P}) \mathrm{H}$. Plant $\mathrm{P} 450$ s are involved in the biosynthesis of primary and secondary metabolites with diverse biological functions. Among others, they are involved in phytoalexin biosynthesis and hormone metabolism [50,51].

Phytoalexins are low molecular weight antimicrobial compounds produced by plants during the attack of a wide variety of plant pathogens. The phytoalexins produced are host-specific, such as camalexin in Arabidopsis [52], some diterpenoids in rice [53], gliceollins in soybeans [54], and serotonin in wheat [55]. Chamalexin is derived from tryptophan and the enzyme CYP is involved in the biosynthesis of chamelexin. In the absence of phytoalexin production plants become vulnerable to attack by a number of pathogens [56]. In Arabidopsis, several phytoalexin-deficient (pad= phytoalexin-deficient) mutants have been identified that were unable to accumulate the phytoalexin chamalexin after infection with the pathogen. The pad3 mutant impaired resistance to Alternaria brassicicola infection [57], while the pad4 mutant is characterized by increased susceptibility to a number of pathogens [58].

As a result of our plant conditioning treatment, an increase in the expression levels of EDS1-2 and PAD4 (Enhanced Disease Susceptibility1 and its co-regulator Phytoalexin Deficient4) enzymes were observed, which promote increased phytoalexin production. According to EDS1 and PAD4 [59] are well-known regulators of both basal and resistance (R) gene-mediated resistance. Two EDS1-like (GmEDS1a / GmEDS1b) and one PAD4-like (GmPAD4) proteins have been identified in soybeans that are required for signal transduction of resistance. Although the expressions of EDS1 and PAD4 genes were increased by biotic stressors, this was not resulted in an increase in SA level.

At the same time, soybean plants showed increased resistance to Pseudomonas syringae pv glycinea. Studies in Arabidopsis plants have revealed associations between the SA pathway and the EDS1-2/PAD4 genes involved in the functioning of this pathway. Until recently, it has been hypothesized that these two enzymes are involved in the SA pathway, but a new research suggests that they operate independently but in parallel pathways [60]. Genetic and transcriptomic data also revealed an EDS1/PAD4-regulated branch being independent of SA in basal and TNL immunity [58, 61-64]. The EDS1-2/PAD4 pathway contributes to plant protection as a kind of helper mechanism when functioning of the SA pathway is insufficient. When gene expression in the SA pathway following the pathogen attack is inadequate, the EDS1-2/PAD4 pathway is also activated. In the putative system, EDS1-2 and PAD4, in addition to associated SA biosynthesis, maintain important SA-related resistance function, thereby increasing the strength of inherent immunity [60].

The Enhanced Disease Susceptibility5 (EDS5) gene is also closely related to the plant protection system, resulting in increased disease resistance. In healthy plants, the level of EDS5 gene expression is markedly low, but it significantly increases in parallel with the EDS1-2/PAD4 pathway upon infection [65]. Although the level of EDS5 enzyme in healthy plants is extremely low, the biostimulant ELICE16INDURES successfully induced the higher expression of that gene in our experiment, thus strengthening the disease resistance of the plants. The EDS5 protein also elicits immunity induced by basal or pathogen-associated molecular patterns [59, 65].

The initial steps of the JA biosynthetic pathway include sequential conversion of $\alpha$-linolenic acid (LnA) to OPDA by lipoxygenase (LOX), allene-oxide-synthase (AOS), and allene-oxide-cyclase (AOC), which operate in the chloroplasts [66-68]. LOX enzymes and oxylipins-enzymatic formation derived from lipid hydroperoxides-produced by them also play a significant role in the defense responses of pathogen-infected plants. Oxylipines such as jasmonates and octadecanoids are oxygen-saturated compounds derived from polyunsaturated fatty acids. While SA regulates 
protection against biotrophic pathogens, JA and methyl-JA (MeJA) primarily regulate immunity to necrotrophic pathogens and pests [69]. Jasmonates include JA which can be metabolized to MeJA and to its biologically active form JA-isoleucine (JA-Ile) [12, 70].

Octadecanoids include 12-oxophytodienolic acid (OPDA) and its derivatives. These compounds are synthesized by one of the seven different branches of the LOX pathway, the initial compound of which is $\alpha$-linolenic acid ( $\alpha$-LnA) [71]. The primary mediator of the damage response is JA, and the synthesis of OPDA is a crucial step in its formation. OPDA synthesis is catalyzed by the AOC enzyme [72]. The immunostimulator used in this study increased the activity of the LOX enzyme, which plays an important role in catalyzing the biosynthesis of JA. The expression level of AOC which is another key enzyme in the synthesis of JA-was also increased. This enzyme catalyzes the formation of the OPDA precursor. SA is critical to SAR, but ISR is less dependent on SA and mainly regulated by JA and ET [12, 73]. One possible explanation for this is that MAPK kinases suppress the SA pathway and induce the JA pathway, activating defensins coded by a group of defensive genes.

The former finding is also supported by a spectacular increase in the expression level of the enzyme methyl ketone synthase (MKS-1,2) in our experiment. MKS enzymes are induced by MAPK/ERK (MEKK) enzymes and MEKK enzymes are involved in MeJa synthesis. Thus, we indirectly demonstrated that our immunostimulator stimulated MeJa synthesis, resulting in the activation of some defensin genes. The significant role of defensins in the development of immune responses has also been demonstrated recently in soybean [74].

An additional cellular response is a sudden increase in the levels of plant glutathione S-transferases (GST). GSTs are ubiquitous multifunctional enzymes encoded by large gene families. The complexing and detoxifying effects of glutathione have long been known [75, 76], but new research has also revealed novel features [77]. A characteristic feature of GST genes is that their expression can be triggered by a wide range of stress condition. Numerous transcriptomic studies have demonstrated that distinct groups of GSTs are specifically induced in the early stages of bacterial, viral, and fungal infections. Several studies demonstrated that the up- or downregulation of GSTs greatly influences the rate of pathogen proliferation and thus the severity of the course of infections [77]. The expression level of the GST enzyme, which is involved in general cell detoxification processes was also increased in our experiment. It is well documented that GST enzymes in higher plants may be induced by a variety of fungal pathogens, xenobiotics, and elicitors, wounding, and phytohormones [78-82].

\section{Changes in gene expression levels (\%)}

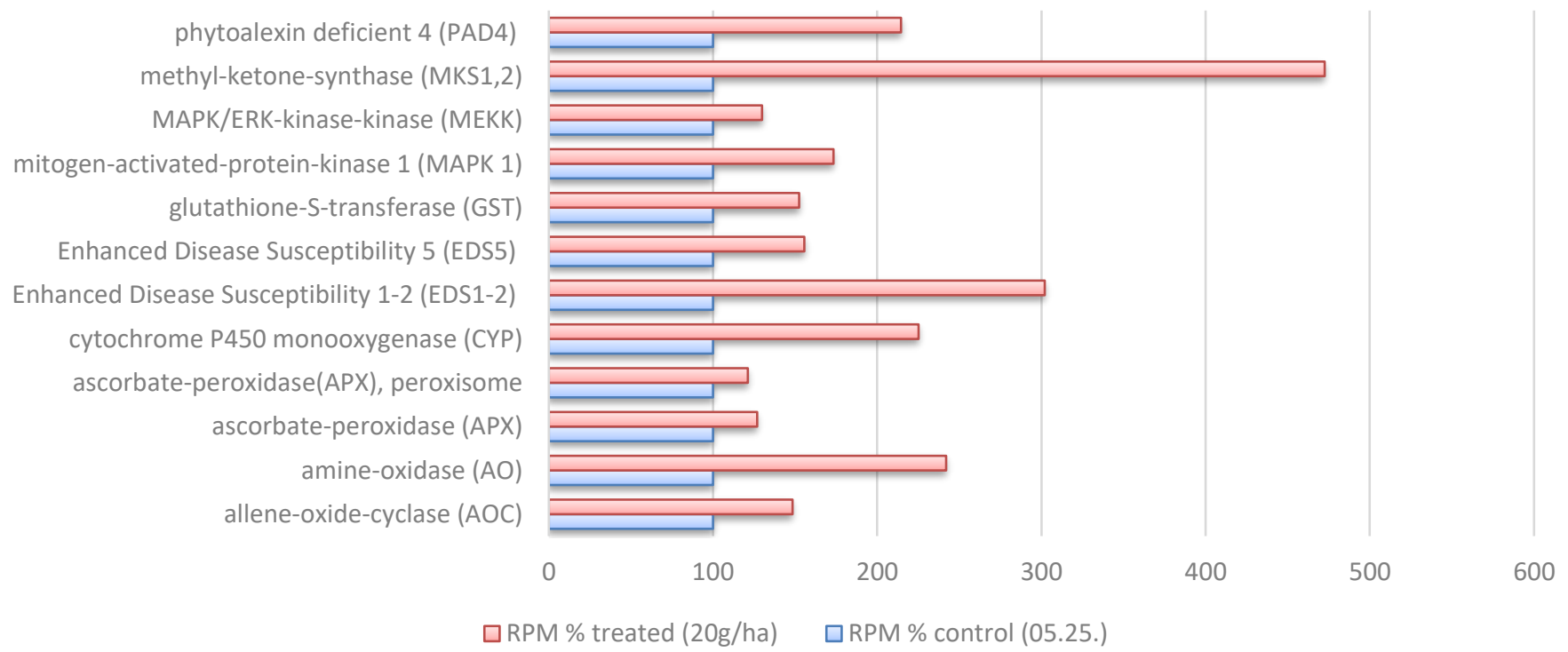

Figure 2: Gene expression levels of control and population treated by lower dose of plant conditioner after the first treatment

In the population treated by lower dose of plant conditioner after the second treatment 786,171 of 10,059,111 reads were assembled to 23 reference sequences and produced 23 contigs.

Treatment with a lower dose, but at a later time (Fig. 3) increased the gene expression of some enzymes in the MAPK cascade in plants. In addition, the expression levels of NADPH oxidase (NOX) and SOD enzymes were also 
increased. NOX uses oxygen to produce superoxide anions $\left(\mathrm{O}_{2}{ }^{-}\right)$, and SOD catalyzes the conversion of the superoxide radical to $\mathrm{H}_{2} \mathrm{O}_{2}$ in the organisms, so the enhanced defense function of the plant cell wall is also manifested here.

Plasma membrane NOXs are key producers of ROS, and play important roles in the regulation of plant-pathogen interactions. Zhang et al. (2019) [83] performed a comprehensive analysis of the NOX gene family in the soybean genome (Glycine max) and 17 NOX (GmNOX) genes were identified. It is already proved that the stresses produced in plants by high temperatures, drought, toxic metals, salinity, and biotic pathogenes can cause molecular damage directly or indirectly through the formation of ROS. To scavenge ROS and to avoid oxidative damage, efficient enzymatic and non-enzymatic antioxidant systems are present in the cells. One of them in soybean is SOD, an enzyme that alternately catalyzes the dismutation (or partitioning) of the superoxide $\left(\mathrm{O}_{2}^{\bullet}-\right)$ radical - produced as a by-product of oxygen metabolism - into ordinary molecular oxygen $\left(\mathrm{O}_{2}\right)$ and hydrogen peroxide $\left(\mathrm{H}_{2} \mathrm{O}_{2}\right)$ [84, 85].

Besides NOXs, oxalate oxidases $(\mathrm{OxO})$ and apoplast AOs are enzymatic sources of ROS production [86-89]. These $\mathrm{H}_{2} \mathrm{O}_{2}$-generated enzymes have been shown to mediate lignification and cross-linking, and programmed cell death in response to both normal growth and biotic and abiotic stresses [89-94]. The level of AO enzyme, which catalyzes the synthesis locally in different cellular organs produced $\mathrm{H}_{2} \mathrm{O}_{2}$, also increased in our experiment. The level of APXs responsible for neutralizing the already redundant $\mathrm{H}_{2} \mathrm{O}_{2}$ also increased. Similar to the results of the first sampling time, gene expressions of CYP450 monooxygenase, EDS1-2, EDS5, and IFS enzymes were increased, enhancing the induction of phytoalexin production. Lozovaya et al. (2007) [95] transformed soybean roots with genes derived from the enzymes CHS and IFS, leading to increased phytoalexin (gliceollin) production and resistance to pathogenic fungi.

At the cellular level, malonyl-CoA is formed from acetyl-CoA using the enzyme acetyl-CoA-carboxylase (ACC). The compound is then converted to flavonoids by chalcone synthase (CHS) and coumaroyl-CoA, which are cyclized by chalcone isomerase (CHI). Cyclization results in the formation of flavanone derivatives. These undergo further transformation in processes catalyzed by particular enzymes. Although the central pathway for flavonoid biosynthesis is conserved in plants, depending on the species, a group of enzymes, such as hydroxylases, reductases, isomerases, and several dioxygenases modify the basic flavonoid skeleton, leading to the different flavonoid subclasses [96]. Flavone synthase (FS) produces flavones, isoflavone synthase (IFS) synthesizes isoflavones, while isoflavone hydroxylase (IH), pterocarpane synthase (PTS), and pterocarpane hydroxylase (PTH) together form pterocarpans. Glycinol, a precursor compound of phytoalexins (gliceollidine, gliceollin), is derived from pterocarpane by further transformation [97]. Lygnin et al. (2013) [98] demonstrated that rapid accumulation of gliceollin during infection contributes to the inherent protective response in soybeans. In addition, according to these authors, the level of the enzyme LOX, which plays a role in the production of oxylipins (e.g., JA), was also increased.

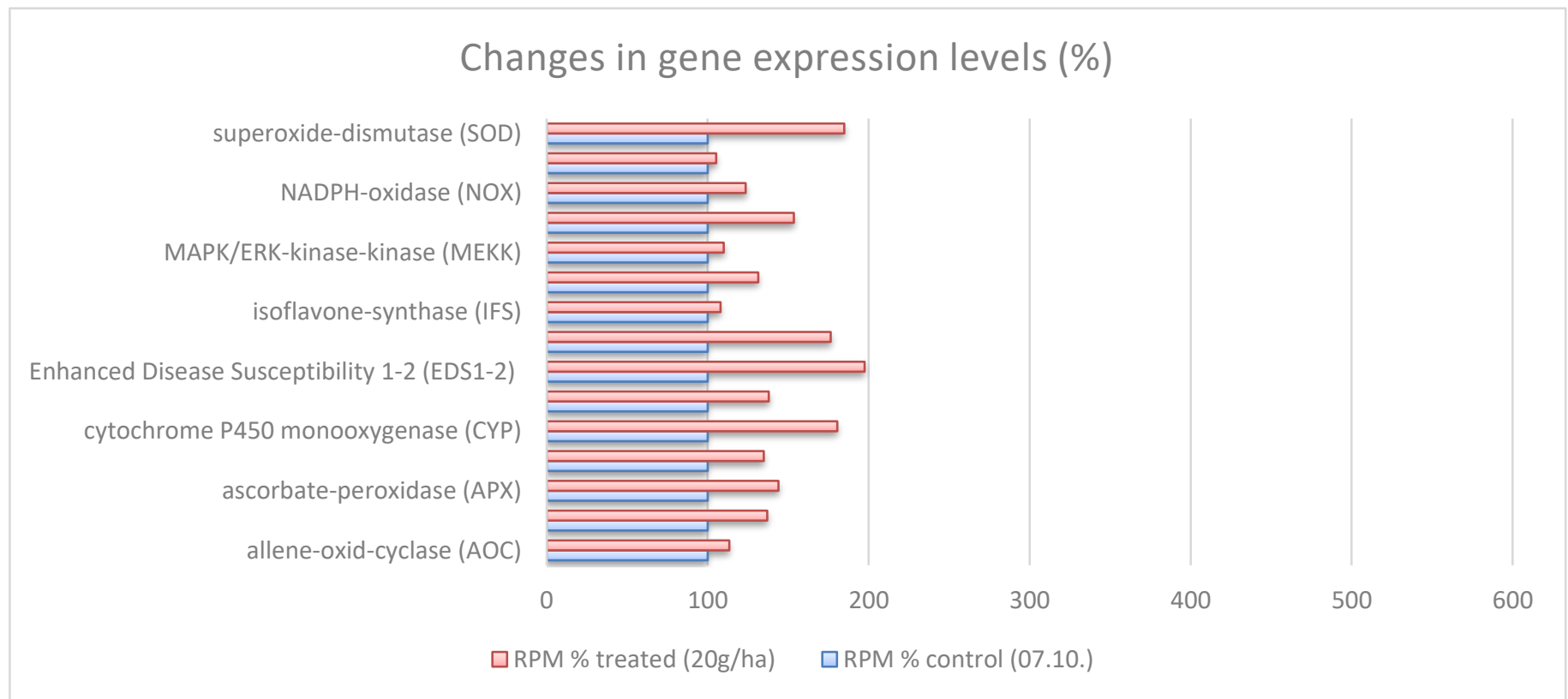

Figure 3: Gene expression levels of control and population treated by lower dose of plant conditioner after the second treatment

In the population treated by higher dose of plant conditioner after the first treatment 722,540 of 9,892,689 reads were assembled to 23 reference sequences and produced 23 contigs. 
In the higher dose-treated population, the expression levels of the MAP cascade, MEKK and MKS 1,2 enzymes increased at the first treatment time (Fig. 4), proving that all of them are responsible for defensin production. The expression levels of SOD and APX enzymes involved in primary cell wall thickening were significantly increased; while CHS, IFS and EDS1-2/PAD4-enzymes that support phytoalexin synthesis - were elevated. Ultimately, the expression level of the GST enzyme responsible for cell detoxification processes was also increased.

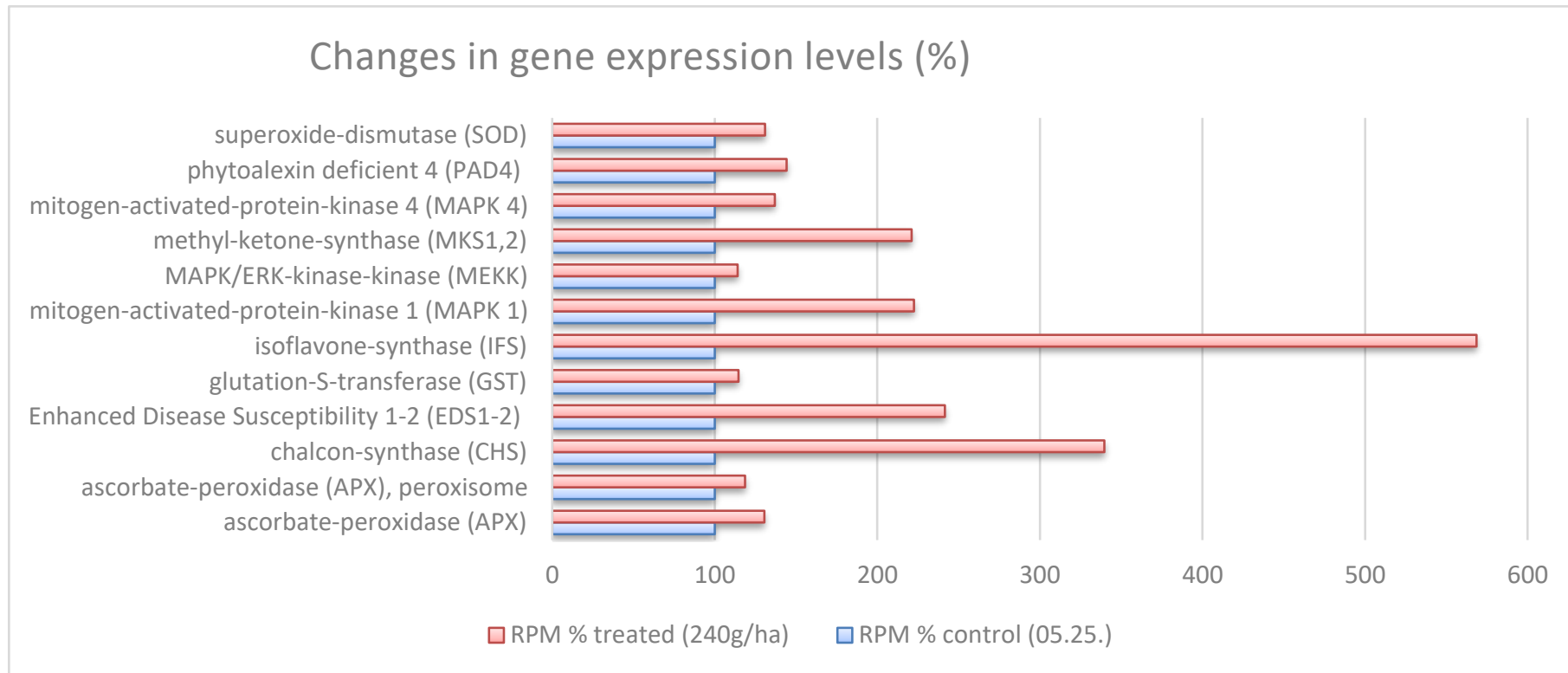

Figure 4: Gene expression levels of control and population treated by higher dose of plant conditioner after the first treatment

In the population treated by higher dose of plant conditioner after the second treatment 566,317 of 8,795,753 reads were assembled to 23 reference sequences and produced 23 contigs.

A higher dose of the plant conditioner at a later time (Fig. 5) induced the MAPK cascade and increased NOX activity, and the latter promotes the production of reactive oxygen species involved in cell wall thickening. In addition, the level of the enzyme ACC, the first enzyme in the pathway that initiates the production of phytoalexins [99] has been increased. The ACC enzyme converts acetyl-CoA to malonyl-CoA. CHS, which induces the second step of the pathway, promotes the formation of the flavonoid structure and also increases the gene expression levels of IFS enzymes, which catalyze the biosynthesis of isoflavones. The change in the expression levels of the additional enzymes studied in our work did not show a significant difference as a result of the treatments.

\section{Changes in gene expression levels (\%)}

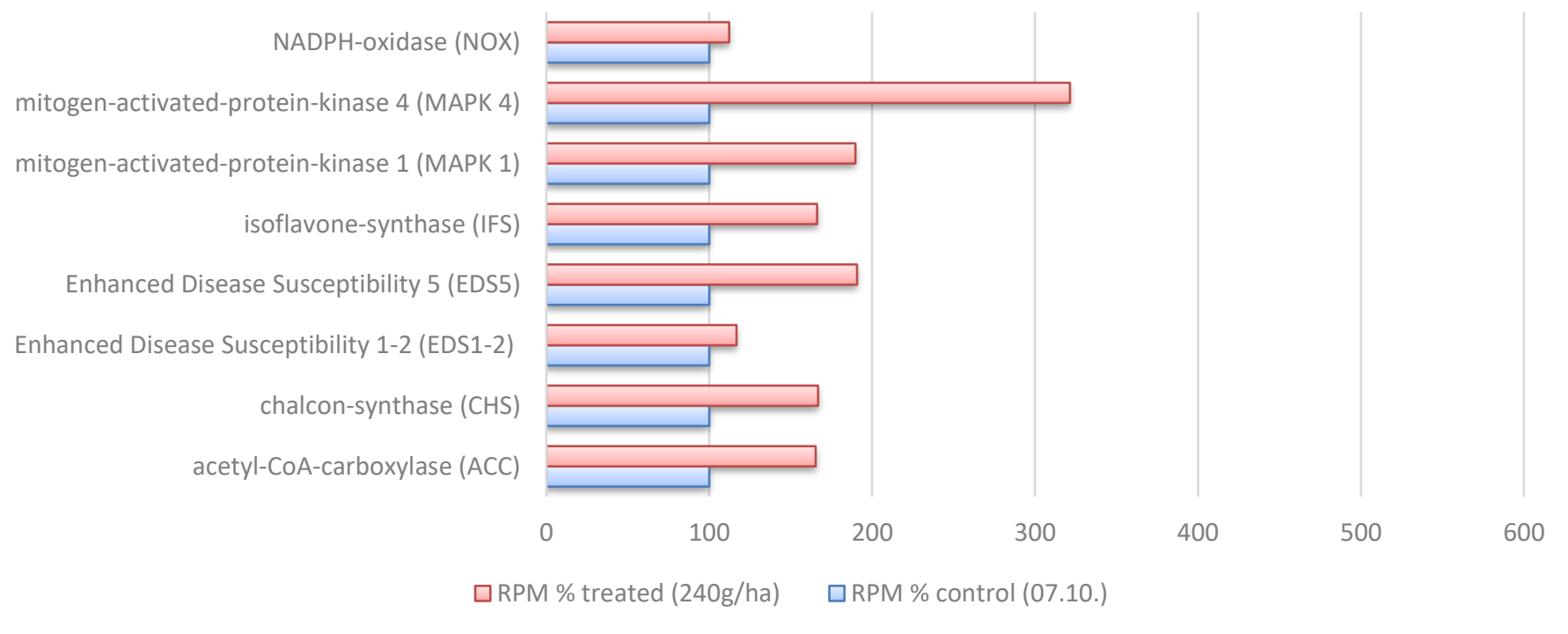


Figure 5: Gene expression levels of control and population treated by higher dose of plant conditioner after the second treatment

Table 1.: Annotation of the genes induced by treatments in this study. 


\begin{tabular}{|c|c|c|c|c|c|}
\hline SeqName & Description & GO IDs & GO Names & Enzyme Codes & Enzyme Names \\
\hline TRINITY_DN16_c0_g1 & $\begin{array}{l}\text { glutathione-s- } \\
\text { transferase } 3\end{array}$ & P:GO:0006749; F:GO:0004364; & $\begin{array}{l}\text { P:glutathione metabolic process; } \\
\text { F:glutathione transferase } \\
\text { activity; }\end{array}$ & $E C: 2.5 .1 .18$ & $\begin{array}{l}\text { glutathione-s- } \\
\text { transferase } 3\end{array}$ \\
\hline TRINITY_DN10910_c0_g1 & $\begin{array}{l}\text { superoxide } \\
\text { dismutase } 1\end{array}$ & C:GO:0016020; C:GO:0016021 & $\begin{array}{l}\text { C:membrane; C:integral } \\
\text { component of membrane }\end{array}$ & EC:1.15.1.1 & $\begin{array}{l}\text { superoxide- } \\
\text { dismutase } 1\end{array}$ \\
\hline TRINITY_DN13696_c0_g1 & $\begin{array}{l}\text { allene-oxide } \\
\text { cyclase }\end{array}$ & P:GO:0006355; P:GO:0015031; & $\begin{array}{l}\text { P:regulation of transcription, } \\
\text { DNA-templated; P:protein } \\
\text { transport; }\end{array}$ & EC:5.3.99.6 & allene-oxyde-cyclase \\
\hline TRINITY_DN4965_c0_g1 & $\begin{array}{l}\text { mitogen- } \\
\text { activated } \\
\text { protein kinase } \\
4\end{array}$ & $\begin{array}{l}\text { P:GO:0007165; P:GO:0055085; } \\
\text { F:GO:0000155; }\end{array}$ & $\begin{array}{l}\text { P:signal transduction; } \\
\text { P:transmembrane transport; } \\
\text { F:phosphorelay sensor kinase } \\
\text { activity; }\end{array}$ & EC:2.7.11.24 & $\begin{array}{l}\text { Mitogen-activated } \\
\text { protein kinase } 4\end{array}$ \\
\hline TRINITY_DN4132_c0_g1 & $\begin{array}{l}\text { mitogen- } \\
\text { activated } \\
\text { protein kinase } \\
\text { kinase kinase } \\
\text { 1-like isoform } \\
\text { X1 }\end{array}$ & P:GO:0000165; F:GO:0004709; & $\begin{array}{l}\text { P:MAPK cascade; F:MAP kinase } \\
\text { kinase kinase activity; }\end{array}$ & EC:2.7.11.25 & $\begin{array}{l}\text { Mitogen-activated } \\
\text { protein kinase } \\
\text { kinase kinase }\end{array}$ \\
\hline TRINITY_DN14164_c0_g1 & $\begin{array}{l}\text { respiratory } \\
\text { burst oxidase } \\
\text { homolog } \\
\text { protein C }\end{array}$ & $\begin{array}{l}\text { P:GO:0051607; P:GO:0098869; } \\
\text { F:GO:0004601; F:GO:0016174; }\end{array}$ & $\begin{array}{l}\text { P:defense response to virus; } \\
\text { P:cellular oxidant detoxification; } \\
\text { F:peroxidase activity; F:NAD(P)H } \\
\text { oxidase } \mathrm{H} 2 \mathrm{O} 2 \text {-forming activity; }\end{array}$ & $\begin{array}{l}\text { EC:1.6.3.1; } \\
\text { EC:1.11.1 }\end{array}$ & $\begin{array}{l}\mathrm{NAD}(\mathrm{P}) \mathrm{H} \text { oxidase } \\
(\mathrm{H}(2) \mathrm{O}(2) \text {-forming); } \\
\text { Acting on a peroxide } \\
\text { as acceptor }\end{array}$ \\
\hline TRINITY_DN17316_c0_g1 & $\begin{array}{l}\text { isoflavone } \\
\text { synthase } 2\end{array}$ & P:GO:0009717; F:GO:0102604; & $\begin{array}{l}\text { P:isoflavonoid biosynthetic } \\
\text { process; F:2- } \\
\text { hydroxyisoflavanone synthase } \\
\text { activity; }\end{array}$ & $\begin{array}{l}\text { EC:1.14.14.87; } \\
\text { EC:1.14.13.86 }\end{array}$ & $\begin{array}{l}\text { 2- } \\
\text { hydroxyisoflavanone } \\
\text { synthase; }\end{array}$ \\
\hline TRINITY_DN603_c0_g1 & $\begin{array}{l}\text { acetyl-CoA } \\
\text { carboxylase } 1\end{array}$ & P:GO:2001295; F:GO:0003989; & $\begin{array}{l}\text { P:malonyl-CoA biosynthetic } \\
\text { process; F:acetyl-CoA } \\
\text { carboxylase activity; }\end{array}$ & EC:6.4.1.2 & $\begin{array}{l}\text { Acetyl-CoA } \\
\text { carboxylase }\end{array}$ \\
\hline TRINITY_DN18316_c0_g1 & $\begin{array}{l}\text { cytochrome } \\
\text { P450 83B1 }\end{array}$ & F:GO:0004497; F:GO:0016705; & $\begin{array}{l}\text { F:monooxygenase activity; } \\
\text { F:oxidoreductase activity, }\end{array}$ & EC:1.14 & $\begin{array}{l}\text { Acting on paired } \\
\text { donors, with } \\
\text { incorporation or } \\
\text { reduction of } \\
\text { molecular oxygen. }\end{array}$ \\
\hline TRINITY_DN3368_c0_g1 & $\begin{array}{l}\text { chalcone } \\
\text { synthase }\end{array}$ & P:GO:0009813; F:GO:0016210 & $\begin{array}{l}\text { P:flavonoid biosynthetic } \\
\text { process; F:naringenin-chalcone } \\
\text { synthase activity }\end{array}$ & $E C: 2.3 \cdot 1.74$ & Chalcone synthase \\
\hline
\end{tabular}


Our examinations were carried out on the soybean tables of PlantArt Research Ltd. in the outskirts of the town of Tata, Hungary, in 2020. Samples were taken from both untreated plots and plots treated with ELICE16INDURES plant conditioner at doses of $20 \mathrm{~g} \cdot \mathrm{ha}^{-1}$ and $240 \mathrm{~g} \cdot \mathrm{ha}^{-1}$, applied two times (25 May, 2020 and $10 \mathrm{July}$, 2020), and sampled two days after treatments. Fresh leaf samples were collected in RNA-shield (Zymo Research, Irvine, US) preservative, then sequenced by Xenovea Ltd, Szeged, Hungary. Data were validated, followed by a full bioinformatics analysis of the sequencing results.

\section{Sample sequencing protocol}

Approximately $30 \mathrm{mg}$ of plant tissues were placed in a $1.5 \mathrm{ml}$ Eppendorf LoBind tube containing glass beads (1.7$2.1 \mathrm{~mm}$ diameter, Carl Roth, Karlsruhe, Germany) and $100 \mu \mathrm{l}$ of TRI-Reagent (Zymo Research, Irvine, US). The Eppendorf tubes were firmly attached to a SILAMAT S5 vibrator (Ivoclar Vivadent, Schaan, Liechtenstein) in order to disrupt and homogenize the tissue for 2x15s. Total RNA was extracted using Direct-zol ${ }^{\mathrm{TM}}$ RNA MiniPrep System (Zymo Research, Irvine, US) according to the manufacturer's protocol. The RNA Integrity Numbers and RNA concentration were determined by RNA ScreenTape system with 2200 Tapestation (Agilent Technologies, Santa Clara, CA, US) and RNA HS Assay Kit with Qubit 3.0 Fluorometer (Thermo Fisher Scientific, Waltham, MA, US), respectively. The analyses were completed by Xenovea Ltd, Szeged Hungary.

For the construction of Gene Expression Profiling (GEx) library, QuantSeq 3' mRNA-Seq Library Prep Kit FWD for Illumina (Lexogen $\mathrm{GmbH}$, Wien, Austria) was applied according to the manufacturer's protocol. The quality and quantity of the library was determined by using High Sensitivity DNA1000 ScreenTape system with 2200 Tapestation (Agilent Technologies, Santa Clara, CA, USA) and dsDNA HS Assay Kit with Qubit 3.0 Fluorometer (Thermo Fisher Scientific, Waltham, MA, US), respectively. Pooled libraries were diluted to $1.8 \mathrm{pM}$ for 1x86 bp single-end sequencing with 75-cycle High Output v2 Kit on the NextSeq 550 Sequencing System (Illumina, San Diego, CA, US), according to the manufacturer's protocol.

\section{Preprocessing}

Bioinformatical softwers were used to data analyses and evaluation. During pre-processing, qualitative analysis was performed and raw sequencing data consisted of $80 \mathrm{bp}$ long single-end sequences were prepared from which the transcriptomes were reconstructed, the reference transcriptome was prepared, and gene expression analyzes were performed. During pre-processing, reads were purified sample-by-sample (filtered for Q30 and ' $\mathrm{N}^{\prime}$ ).

\section{Quality control and filtering of libraries}

The analysis is performed by a nine-module FastQC program [100], which provides a quick overview of whether the data are suitable for further analysis and whether there are any problems or distortions in the read sequences that affect further analysis. Statistics were generated from filtered reads. During purification, reads and bases containing adapters, contaminant sequences, and short or poor quality reads due to possible sequencing errors were filtered out from the raw data. Screening was performed with Trimmomatic and GenoUtils [100, 101]. Filtered directories are named clean-prefixed. SRA (unassembled sequence reads) data was deposited in the NCBI under the accession PRJNA778970, SRA submission SUB10637174.

\section{Computer Processing of Samples and Creating a Reference Transcript Database}

To create the reference, the sequenced libraries were treated together. The pooled reads were combined with a 3module Trinity program based on the Bruijn graph in order to reconstruct the longest possible mRNA fragments (transcripts) from the short readings $(80 \mathrm{bp})$. The Trinity program allows de novo assembly. When running Trinity, we worked with a value of a $25 \mathrm{~K}$-mer, saving files in fasta extension. Gene-level analyses were performed from generated data [102, 103]. TSA (Transcriptome Shotgun Assembly) data was deposited in the NCBI under the accession PRJNA778970, TSA temporary submission SUB10815164.

\section{Using a reference transcript to search for unique sequences}

Gene sequences of enzymes involved in the metabolic processes that may be affected by the immunochemical used in the experiment were collected from known related species (Glycine max and Glycine soybean) using the NCBI public database (https://www.ncbi.nlm.nih. gov/nuccore). In the next step, we retrieved the expressed contigs from our own reference transcriptome database using the Blast+ alignment program [104]. 


\section{Matching short reads to reference sequences}

Using Geneious Prime 9.0 bioinformatics software [105], short reads of transcripts obtained from the samples of the control and those from two different dose-treated strains were aligned to the reference sequences, and these data were further analyzed. First, individual RPM (Reads per million mapped read) values were calculated for each gene (equation is shown below), and these values were then plotted on figures separately for each treatment and time point.

$$
\text { RPM }=\frac{\text { mapped reads to a gene } \times 10^{6}}{\text { total mapped reads }}
$$

In some special RNA-seq protocols, especially in the shallow RNA-seq methods, reads are generated only from one end of the RNA molecule, regardless of the length of the molecule. Since RPM does not take transcript length into account, this unit reflects the actual number of transcripts more accurately. From the RPM values we obtained the individual expression levels of the enzyme sequences operating in the given treatment at a given time, i.e. the degree of their really expression. From the RPM values we obtained the individual expression levels of the enzyme sequences reacting to the treatments applied at a given time, that is, the degree of their expression [106].

\section{Functional annotation}

Functional annotation and Gene Ontology (GO) analyses were carried out using OmixBox, Biobam, as follows: 1. Sequences were blasted against NCBI nr (non-redundant) Viridiplantae database (downloaded in 2019) applying blastn configuration locally; 2 . To retrieving GO terms associated with the 10 Hits obtained by the Blast search, GO mapping and annotation were performed. GeneBank identifiers (gi) and the primary blast Hit identifiers were used to retrieve UniProt IDs making use of a mapping file from PIR (Non-redundant Reference Protein Database) including PSD, UniProt, Swiss-Prot, TrEMBL, RefSeq, GenPept and PDB. Accessions were searched directly in the db x ref table of the GO database. BLAST results were searched directly in the gene-product table of the GO database; 3 . GO annotation were specified according to GO terms of molecular function, cellular component, and biological process.

\section{Conclusions}

In our experiments, it has been found that some of the pathogen-induced immune responses of plants can also be elicited using certain immunochemicals. Pathogen-induced SAR (systemic acquired resistance) tends to activate the SA pathway, while priming-induced ISR (induced systemic resistance) triggers other pathways, mainly JA and ET biosynthesis. The results of our experiment are in accordance of these in soybean treated with a plant conditioner, thus proving that ISR can be induced by a natural immunochemical without the presence of a pathogen. General immunity is an inherent, genetically encoded trait of a plant that provides protection to organisms that are not otherwise able to defend themselves through metabolic pathways. Although the plant conditioner used did not increase the expression of all the genes involved in the defense, it activated some of the primary plant responses immediately after infection (e.g., cell wall thickening, accumulation of phenolic compounds, activation of antioxidant enzymes, etc.). Due to its effect, the long-term use of similar immunochemicals has a beneficial immune-boosting effect on the plants. Another advantage of the plant conditioner investigated here (ELICE16INDURES) is that its ingredients can be used in the long run, and so this also can be a sustainable, environmentally safe way of agricultural production. Thus, plant-based antimicrobial agents may also provide an excellent alternative for organic farmers.

\section{Author Contributions:}

K. Decsi: data curation, formal analysis, validation, writing - original draft

B. Kutasy: project administration, visualization

M. Kiniczky: data curation, investigation

G. Hegedűs: methodology, software

Z. Alföldi: writing - review and editing

N. Kálmán: data curation, investigation

Á. Nagy: conceptualization, project administration 


\section{Zs. Thomas-Nyári: project administration}

E. Virág: conceptualization, methodology, software, supervision

All authors have read and agreed to the published version of the manuscript.

Funding: The work was supported by the KFI_16-1-2017-0457 - Development and production of a plant based pesticide-plant conditioner for use in organic farming - project of the Hungarian Government. We express our thanks to the Xenovea Ltd, Hungary to perform NGS library preparation and sequencing. We are grateful to the editor and reviewers for the valuable comments that have helped to improve the manuscript.

Data Availability Statement: SRA (unassembled sequence reads) data was deposited in the NCBI under the accession PRJNA778970, SRA submission SUB10637174. TSA (Transcriptome Shotgun Assembly) data was deposited in the NCBI under the accession PRJNA778970, TSA temporary submission SUB10815164 .

Acknowledgments: We express our thanks to the Xenovea Ltd, Hungary to perform NGS library preparation and sequencing and Edit Dulovics, Pannon natesex Ltd, Kajdacs, Hungary to the conceptualization of the herb extracts.

Conflicts of Interest: The authors declare no conflict of interest.

\section{References}

1. Szatmari A, Ott PG, Varga GJ, Besenyei E, Czelleng A, Klement Z and Bozsó Z (2006) Characterisation of basal resistance (BR) by expression patterns of newly isolated representative genes in tobacco. Plant cell reports 25:728-740. doi: 10.1007/s00299-005-01105

2. Cohn J, Sessa G and Martin GB (2001) Innate immunity in plants. Current opinion in immunology 13:55-62. doi: 10.1016/S09527915(00)00182-5

3. Amari K and Niehl A (2020) Nucleic acid-mediated PAMP-triggered immunity in plants. Current Opinion in Virology 42:3239. doi: 10.1016/j.coviro.2020.04.003

4. Mogensen TH (2009) Pathogen recognition and inflammatory signaling in innate immune defenses. Clinical microbiology reviews 22:240-273. doi: 0.1128/CMR.00046-08

5. Ausubel FM (2005) Are innate immune signaling pathways in plants and animals conserved? Nature immunology 6:973-979. doi: $10.1038 /$ ni1253

6. Bittel P and Robatzek S (2007) Microbe-associated molecular patterns (MAMPs) probe plant immunity. Current opinion in plant biology 10:335-341. doi: 10.1016/j.pbi.2007.04.021

7. Boller T and Felix G (2009) A renaissance of elicitors: perception of microbe-associated molecular patterns and danger signals by pattern-recognition receptors. Annual review of plant biology 60:379-406. doi: 10.1146/annurev.arplant.57.032905.105346

8. Chisholm ST, Coaker G, Day B and Staskawicz BJ (2006) Host-microbe interactions: shaping the evolution of the plant immune response. Cell 124:803-814. doi: 10.1016/j.cell.2006.02.008

9. Jones JD and Dangl JL (2006) The plant immune system. nature 444:323-329. doi: 10.1038/nature05286

10. Heath MC (2000) Nonhost resistance and nonspecific plant defenses. Current opinion in plant biology 3:315-319. doi: 10.1016/S1369-5266(00)00087-X

11. Zhou M and Wang W (2018) Recent advances in synthetic chemical inducers of plant immunity. Frontiers in plant science 9:1613. doi: 10.3389/fpls.2018.01613

12. Pieterse CM, Zamioudis C, Berendsen RL, Weller DM, Van Wees SC and Bakker PA (2014) Induced systemic resistance by beneficial microbes. Annual review of phytopathology 52:347-375. doi: 10.1146/annurev-phyto-082712-102340

13. Conrath U, Gerold J M Beckers J, Flors V, García-Agustín P, Jakab G, Mauch F, Newman M, Pieterse C, Poinssot B, Pozo M, Pugin A, Schaffrath U, Ton J, Wendehenne D, Zimmerli L and Mauch-Mani B (2006) Priming: getting ready for battle. Molecular Plant Microbe Interact. doi: 10.1094/MPMI-19-1062

14. Cui Z, Ito J, Dohi H, Amemiya Y and Nishida Y (2014) Molecular design and synthesis of novel salicyl glycoconjugates as elicitors against plant diseases. PLoS One 9:e108338. doi: 10.1371/journal.pone.0108338 
15. Métraux J, Ahlgoy P, Staub T, Speich J, Steinemann A, Ryals J and Ward E (1991) Induced systemic resistance in cucumber in response to 2, 6-dichloro-isonicotinic acid and pathogens. Advances in Molecular Genetics of Plant-Microbe Interactions Vol. 1, Springer, pp. 432-439

16. Ward ER, Uknes SJ, Williams SC, Dincher SS, Wiederhold DL, Alexander DC, Ahl-Goy P, Metraux J-P and Ryals JA (1991) Coordinate gene activity in response to agents that induce systemic acquired resistance. The Plant Cell 3:1085-1094. doi: 10.1105/tpc.3.10.1085

17. Uknes S, Mauch-Mani B, Moyer M, Potter S, Williams S, Dincher S, Chandler D, Slusarenko A, Ward E and Ryals J (1992) Acquired resistance in Arabidopsis. The Plant Cell 4:645-656. doi: 10.1105/tpc.4.6.645

18. Kuć J (1982) Induced immunity to plant disease. Bioscience 32:854-860. doi: 10.2307/1309008

19. Schurter R, Kunz W and Nyfeler R (1993) Process and a composition for immunizing plants against diseases. Google Patents,

20. Kunz W, Schurter R and Maetzke T (1997) The chemistry of benzothiadiazole plant activators. Pesticide Science 50:275-282. doi: 10.1002/(SICI)1096-9063(199708)50:4<275::AID-PS593>3.0.CO;2-7

21. Oostendorp M, Kunz W, Dietrich B and Staub T (2001) Induced disease resistance in plants by chemicals. European Journal of Plant Pathology 107:19-28. doi: 10.1023/A:1008760518772

22. Krumm T, Bandemer K and Boland W (1995) Induction of volatile biosynthesis in the Lima bean (Phaseolus lunatus) by leucineand isoleucine conjugates of 1-oxo-and 1-hydroxyindan-4-carboxylic acid: evidence for amino acid conjugates of jasmonic acid as intermediates in the octadecanoid signalling pathway. FEBS letters 377:523-529. doi: 10.1016/0014-5793(95)01398-9

23. Fliegmann J, Schüler G, Boland W, Ebel J and Mithöfer A (2003) The role of octadecanoids and functional mimics in soybean defense responses. doi: 10.1515/BC.2003.049

24. Schüler G, Mithöfer A, Baldwin IT, Berger S, Ebel J, Santos JG, Herrmann G, Hölscher D, Kramell R and Kutchan TM (2004) Coronalon: a powerful tool in plant stress physiology. FEBS letters 563:17-22. doi: 10.1016/S0014-5793(04)00239-X

25. Pluskota WE, Qu N, Maitrejean M, Boland W and Baldwin IT (2007) Jasmonates and its mimics differentially elicit systemic defence responses in Nicotiana attenuata. Journal of experimental botany 58:4071-4082. doi: 10.1093/jxb/erm263

26. Kamatham S, Neela KB, Pasupulati AK, Pallu R, Singh SS and Gudipalli P (2016) Benzoylsalicylic acid isolated from seed coats of Givotia rottleriformis induces systemic acquired resistance in tobacco and Arabidopsis. Phytochemistry 126:11-22. doi: 10.1016/j.phytochem.2016.03.002

27. Cohen Y, Vaknin M and Mauch-Mani B (2016) BABA-induced resistance: milestones along a 55-year journey. Phytoparasitica 44:513-538. doi: 10.1007/s12600-016-0546-x

28. Hegedus G, Kiniczky M, Nagy Á, Pekker P, Lang B, Kleineizel S, Pallos JP, Thomas-Nyári Z, Decsi K and Kutasy BJ (2021) ELICE16INDURES®: a plant immune-priming activator targeting jasmonate metabolism via TIFY and RHOMBOID proteins in Hordeum vulgare. bioRxiv. doi: 10.1101/2021.08.11.455979

29. Tester M and Davenport R (2003) Na+tolerance and Na+ transport in higher plants. Annals of botany 91:503-527. doi: $10.1093 / \mathrm{aob} / \mathrm{mcg} 058$

30. Lee J, Rudd JJ, Macioszek VK and Scheel D (2004) Dynamic changes in the localization of MAPK cascade components controlling pathogenesis-related (PR) gene expression during innate immunity in parsley. Journal of Biological Chemistry 279:2244022448. doi: 10.1074/jbc.M401099200

31. Ahlfors R, Macioszek V, Rudd J, Brosché M, Schlichting R, Scheel D and Kangasjärvi J (2004) Stress hormone - independent activation and nuclear translocation of mitogen - activated protein kinases in Arabidopsis thaliana during ozone exposure. The Plant Journal 40:512-522. doi: 10.1111/j.1365-313X.2004.02229.x

32. Im JH, Lee H, Kim J, Kim HB and An CS (2012) Soybean MAPK, GMK1 is dually regulated by phosphatidic acid and hydrogen peroxide and translocated to nucleus during salt stress. Molecules and cells 34:271-278. doi: 10.1007/s10059-012-0092-4

33. Mizoguchi T, Ichimura K and Shinozaki K (1997) Environmental stress response in plants: the role of mitogen-activated protein kinases. Trends in biotechnology 15:15-19. doi: 10.1016/S0167-7799(96)10074-3 
34. Jonak C, Ökrész L, Bögre L and Hirt H (2002) Complexity, cross talk and integration of plant MAP kinase signalling. Current opinion in plant biology 5:415-424. doi: 10.1016/S1369-5266(02)00285-6

35. Asai T, Tena G, Plotnikova J, Willmann MR, Chiu W-L, Gomez-Gomez L, Boller T, Ausubel FM and Sheen J (2002) MAP kinase signalling cascade in Arabidopsis innate immunity. Nature 415:977-983. doi: 10.1038/415977a

36. Lee HK, Cho SK, Son O, Xu Z, Hwang I and Kim WT (2009) Drought stress-induced Rma1H1, a RING membrane-anchor E3 ubiquitin ligase homolog, regulates aquaporin levels via ubiquitination in transgenic Arabidopsis plants. The Plant Cell 21:622-641. doi: 10.1105/tpc.108.061994

37. Yang K-Y, Liu Y and Zhang S (2001) Activation of a mitogen-activated protein kinase pathway is involved in disease resistance in tobacco. Proceedings of the national academy of sciences 98:741-746. doi: 10.1073/pnas.98.2.741

38. He X, Wang C, Wang H, Li L and Wang C (2020) The function of MAPK cascades in response to various stresses in horticultural plants. Frontiers in Plant Science 11:952. doi: 10.3389/fpls.2020.00952

39. Kroj T, Rudd JJ, Nürnberger T, Gabler Y, Lee J and Scheel D (2003) Mitogen-activated protein kinases play an essential role in oxidative burst-independent expression of pathogenesis-related genes in parsley. Journal of Biological Chemistry 278:2256-2264. doi: 10.1074/jbc.M208200200

40. Wu P, Wang W, Li Y and Hou X (2017) Divergent evolutionary patterns of the MAPK cascade genes in Brassica rapa and plant phylogenetics. Horticulture research 4:1-12. doi: 10.1038/hortres.2017.79

41. Kishi - Kaboshi M, Okada K, Kurimoto L, Murakami S, Umezawa T, Shibuya N, Yamane H, Miyao A, Takatsuji H and Takahashi A (2010) A rice fungal MAMP - responsive MAPK cascade regulates metabolic flow to antimicrobial metabolite synthesis. The Plant Journal 63:599-612. doi: 10.1111/j.1365-313X.2010.04264.x

42. Llorens E, García-Agustín P and Lapeña L (2017) Advances in induced resistance by natural compounds: towards new options for woody crop protection. Scientia Agricola 74:90-100. doi: 10.1590/1678-992X-2016-0012

43. Ott P, Szabó L, Balázs E and Klement Z (1997) Submicroscopic evidence of bacterially induced resistance in tobacco leaves. Acta phytopathologica et entomologica hungarica 32:265-280.

44. Szarka J and Csilléry G (2001a) General defense system in the plant kingdom I. International Journal of Horticultural Science 7:79-84. doi: 10.31421/IJHS/7/1/254

45. Szarka J and Csilléry G (2001b) General defense system in the plant kingdom II. International Journal of Horticultural Science 7:69-71. doi: 10.31421/IJHS/7/3-4/286

46. Angelini R, Cona A, Federico R, Fincato P, Tavladoraki P and Tisi A (2010) Plant amine oxidases "on the move": an update. Plant Physiology and Biochemistry 48:560-564. doi: 10.1016/j.plaphy.2010.02.001

47. Egbichi I, Keyster M and Ludidi N (2014) Effect of exogenous application of nitric oxide on salt stress responses of soybean. South African Journal of Botany 90:131-136. doi: 10.1016/j.sajb.2013.11.002

48. Tsaniklidis G, Delis C, Nikoloudakis N, Katinakis P, Passam HC and Aivalakis G (2014) 1-Ascorbic acid metabolism in parthenocarpic and seeded cherry tomatoes. Plant Growth Regulation 72:141-153. doi: 10.1007/s10725-013-9845-0

49. Guttikonda SK, Trupti J, Bisht NC, Chen H, An Y-QC, Pandey S, Xu D and Yu O (2010) Whole genome co-expression analysis of soybean cytochrome P450 genes identifies nodulation-specific P450 monooxygenases. BMC plant biology 10:1-19. doi: $10.1186 / 1471-2229-10-243$

50. Winkel BS (2004) Metabolic channeling in plants. Annu. Rev. Plant Biol. 55:85-107.

51. Ralston L and Yu O (2006) Metabolons involving plant cytochrome P450s. Phytochemistry Reviews 5:459-472. doi: 10.1007/s11101-006-9014-4

52. Glawischnig E (2007) Camalexin. Phytochemistry 68:401-406. doi: 10.1016/j.phytochem.2006.12.005

53. Li W, Shao M, Yang J, Zhong W, Okada K, Yamane H, Qian G and Liu F (2013) Oscyp71Z2 involves diterpenoid phytoalexin biosynthesis that contributes to bacterial blight resistance in rice. Plant Science 207:98-107. doi: 10.1016/j.plantsci.2013.02.005 
54. Liu Y, Wu Z, Feng S, Yang X and Huang D (2014) Hormesis of glyceollin I, an induced phytoalexin from soybean, on budding yeast chronological lifespan extension. Molecules 19:568-580. doi: 10.3390/molecules19010568

55. Du Fall LA and Solomon PS (2013) The necrotrophic effector SnToxA induces the synthesis of a novel phytoalexin in wheat. New Phytologist 200:185-200. doi: 10.1111/nph.12356

56. Jun X, WANG X-y and GUO W-z (2015) The cytochrome P450 superfamily: Key players in plant development and defense. Journal of Integrative Agriculture 14:1673-1686. doi: 10.1016/S2095-3119(14)60980-1

57. Thomma BP, Eggermont K, Penninckx IA, Mauch-Mani B, Vogelsang R, Cammue BP and Broekaert WF (1998) Separate jasmonate-dependent and salicylate-dependent defense-response pathways in Arabidopsis are essential for resistance to distinct microbial pathogens. Proceedings of the National Academy of Sciences 95:15107-15111.

58. Glazebrook J, Chen W, Estes B, Chang HS, Nawrath C, Métraux JP, Zhu T and Katagiri F (2003) Topology of the network integrating salicylate and jasmonate signal transduction derived from global expression phenotyping. The Plant Journal 34:217-228. doi: 10.1046/j.1365-313X.2003.01717.x

59. Wang J, Shine M, Gao Q-M, Navarre D, Jiang W, Liu C, Chen Q, Hu G and Kachroo A (2014) Enhanced disease susceptibility1 mediates pathogen resistance and virulence function of a bacterial effector in soybean. Plant physiology 165:1269-1284. doi: 10.1104/pp.114.242495

60. Cui H, Gobbato E, Kracher B, Qiu J, Bautor J and Parker JE (2017) A core function of EDS1 with PAD4 is to protect the salicylic acid defense sector in Arabidopsis immunity. New Phytologist 213:1802-1817. doi: 10.1111/nph.14302

61. Zhang Y, Goritschnig S, Dong X and Li X (2003) A gain-of-function mutation in a plant disease resistance gene leads to constitutive activation of downstream signal transduction pathways in suppressor of npr1-1, constitutive 1. The Plant Cell 15:26362646. doi: 10.1105/tpc.015842

62. Bartsch M, Gobbato E, Bednarek P, Debey S, Schultze JL, Bautor J and Parker JE (2006) Salicylic acid-independent ENHANCED DISEASE SUSCEPTIBILITY1 signaling in Arabidopsis immunity and cell death is regulated by the monooxygenase FMO1 and the nudix hydrolase NUDT7. The Plant Cell 18:1038-1051. doi: 10.1105/tpc.105.039982

63. Wang L, Mitra RM, Hasselmann KD, Sato M, Lenarz-Wyatt L, Cohen JD, Katagiri F and Glazebrook J (2008) The genetic network controlling the Arabidopsis transcriptional response to Pseudomonas syringae pv. maculicola: roles of major regulators and the phytotoxin coronatine. Molecular plant-microbe interactions 21:1408-1420. doi: 10.1094/MPMI-21-11-1408

64. Gloggnitzer J, Akimcheva S, Srinivasan A, Kusenda B, Riehs N, Stampfl H, Bautor J, Dekrout B, Jonak C and Jiménez-Gómez JM (2014) Nonsense-mediated mRNA decay modulates immune receptor levels to regulate plant antibacterial defense. Cell host \& microbe 16:376-390. doi: 10.1016/j.chom.2014.08.010

65. Nawrath C, Heck S, Parinthawong N and Métraux J-P (2002) EDS5, an essential component of salicylic acid-dependent signaling for disease resistance in Arabidopsis, is a member of the MATE transporter family. The Plant Cell 14:275-286. doi: 10.1105/tpc.010376

66. Vick BA and Zimmerman DC (1984) Biosynthesis of jasmonic acid by several plant species. Plant physiology 75:458-461. doi: 10.1104/pp.75.2.458

67. Froehlich JE, Itoh A and Howe GA (2001) Tomato allene oxide synthase and fatty acid hydroperoxide lyase, two cytochrome P450s involved in oxylipin metabolism, are targeted to different membranes of chloroplast envelope. Plant Physiology 125:306-317. doi: 10.1104/pp.125.1.306

68. Stenzel I, Hause B, Miersch O, Kurz T, Maucher H, Weichert H, Ziegler J, Feussner I and Wasternack C (2003) Jasmonate biosynthesis and the allene oxide cyclase family of Arabidopsis thaliana. Plant molecular biology 51:895-911. doi: 10.1023/A:1023049319723

69. Santino A, Taurino M, De Domenico S, Bonsegna S, Poltronieri P, Pastor V and Flors V (2013) Jasmonate signaling in plant development and defense response to multiple (a) biotic stresses. Plant cell reports 32:1085-1098. doi: 10.1007/s00299-013-1441-2 
70. Svoboda J and Boland W (2010) Plant defense elicitors: Analogues of jasmonoyl-isoleucine conjugate. Phytochemistry 71:14451449. doi: 10.1016/j.phytochem.2010.04.027

71. Feussner I and Wasternack C (2002) The lipoxygenase pathway. Annual review of plant biology 53:275-297. doi: 10.1146/annurev.arplant.53.100301.135248

72. Fortes AM, Miersch O, Lange PR, Malhó R, Testillano PS, Risueño MdC, Wasternack C and Pais MS (2005) Expression of allene oxide cyclase and accumulation of jasmonates during organogenic nodule formation from hop (Humulus lupulus var. Nugget) internodes. Plant and cell physiology 46:1713-1723. doi: 10.1093/pcp/pci187

73. Pieterse C, J VWSM, A. VPJ, Knoester M LR, H. G, J. WP and LC. VL (1998) A novel signaling pathway controlling induced systemic resistance in Arabidopsis. Plant Cell 10:1571-1580. doi: 10.1105/tpc.10.9.1571

74. Soto N, Hernández Y, Delgado C, Rosabal Y, Ortiz R, Valencia L, Borrás-Hidalgo O, Pujol M and Enríquez GA (2020) Field resistance to Phakopsora pachyrhizi and Colletotrichum truncatum of transgenic soybean expressing the NmDef02 plant defensin gene. Frontiers in Plant Science 11:562. doi: 10.3389/fpls.2020.00562

75. Dudler R, Hertig C, Rebmann G, Bull J and Mauch F (1991) A pathogen-induced wheat gene encodes a protein homologous to glutathione-S-transferases. Mol. Plant-Microbe Interact 4:14-18.

76. Edwards R and Dixon RA (1991) Glutathione S-cinnamoyl transferases in plants. Phytochemistry 30:79-84. doi: 10.1016/00319422(91)84102-X

77. Gullner G, Komives T, Király L and Schröder P (2018) Glutathione S-transferase enzymes in plant-pathogen interactions. Frontiers in plant science 9:1836. doi: 10.3389/fpls.2018.01836

78. Fuerst EP, Irzyk GP and Miller KD (1993) Partial characterization of glutathione S-transferase isozymes induced by the herbicide safener benoxacor in maize. Plant physiology 102:795-802. doi: 10.1104/pp.102.3.795

79. Farago S, Brunold C and Kreuz K (1994) Herbicide safeners and glutathione metabolism. Physiologia Plantarum 91:537-542. doi: 10.1111/j.1399-3054.1994.tb02985.x

80. Hahn K and Strittmatter G (1994) Pathogen - defence gene prp1 - 1 from potato encodes an auxin - responsive glutathione S - transferase. European Journal of Biochemistry 226:619-626. doi: 10.1111/j.1432-1033.1994.tb20088.x

81. Flury T, Adam D and Kreuz K (1995) A 2, 4 - D - inducible glutathione S - transferase from soybean (Glycine max). Purification, characterisation and induction. Physiologia Plantarum 94:312-318. doi: 10.1111/j.1399-3054.1995.tb05317.x

82. Ulmasov T, Ohmiya A, Hagen G and Guilfoyle T (1995) The soybean GH2/4 gene that encodes a glutathione S-transferase has a promoter that is activated by a wide range of chemical agents. Plant physiology 108:919-927. doi: 10.1104/pp.108.3.919

83. Zhang Z, Zhao Y, Feng X, Luo Z, Kong S, Zhang C, Gong A, Yuan H, Cheng L and Wang X (2019) Genomic, molecular evolution, and expression analysis of NOX genes in soybean (Glycine max). Genomics 111:619-628. doi: 10.1016/j.ygeno.2018.03.018

84. Bao X, Bingchang Z and Qinhua L (1989) Study on the superoxide dismutase of soybean seeds from different species in subgenus soja. Acta Botanica Sinica (China).

85. Cardoso J, Machado I, Irigoyen JO and Pistón M (2013) Preliminary study of superoxide dismutase activity in soybean seeds with good and poor in vitro viability used in Uruguay. In: Torre MH and Gambino D (eds) 12th International Symposium on Metal Ions in Biology and Medicine, Montevideo, Uruguay

86. Grant JJ and Loake GJ (2000) Role of reactive oxygen intermediates and cognate redox signaling in disease resistance. Plant physiology 124:21-30. doi: 10.1104/pp.124.1.21

87. Mittler R (2002) Oxidative stress, antioxidants and stress tolerance. Trends in plant science 7:405-410. doi: 10.1016/S13601385(02)02312-9

88. Vranová E, Inzé D and Van Breusegem F (2002) Signal transduction during oxidative stress. Journal of experimental botany 53:1227-1236. doi: 10.1093/jexbot/53.372.1227

89. Cona A, Rea G, Angelini R, Federico R and Tavladoraki P (2006) Functions of amine oxidases in plant development and defence. Trends in plant science 11:80-88. doi: 10.1016/j.tplants.2005.12.009 
90. Pennell RI and Lamb C (1997) Programmed cell death in plants. The Plant Cell 9:1157. doi: 10.1105/tpc.9.7.1157

91. Laurenzi M, Rea G, Federico R, Tavladoraki P and Angelini R (1999) De-etiolation causes a phytochrome-mediated increase of polyamine oxidase expression in outer tissues of the maize mesocotyl: a role in the photomodulation of growth and cell wall differentiation. Planta 208:146-154. doi: 10.1007/s004250050544

92. Rea G, Metoui O, Infantino A, Federico R and Angelini R (2002) Copper amine oxidase expression in defense responses to wounding and Ascochyta rabiei invasion. Plant Physiology 128:865-875. doi: 10.1104/pp.010646

93. Walters D (2003) Resistance to plant pathogens: possible roles for free polyamines and polyamine catabolism. New Phytologist 159:109-115. doi: 10.1046/j.1469-8137.2003.00802.x

94. Yoda H, Yamaguchi Y and Sano H (2003) Induction of hypersensitive cell death by hydrogen peroxide produced through polyamine degradation in tobacco plants. Plant Physiology 132:1973-1981. doi: 10.1104/pp.103.024737

95. Lozovaya VV, Lygin AV, Zernova OV, Ulanov AV, Li S, Hartman GL and Widholm JM (2007) Modification of phenolic metabolism in soybean hairy roots through down regulation of chalcone synthase or isoflavone synthase. Planta 225:665-679. doi: 10.1007/s00425-006-0368-z

96. Martens S, Preuß A and Matern U (2010) Multifunctional flavonoid dioxygenases: flavonol and anthocyanin biosynthesis in Arabidopsis thaliana L. Phytochemistry 71:1040-1049. doi: 10.1016/j.phytochem.2010.04.016

97. Antus S, Gulácsi K, Juhász L, Kiss L and Kurtán T (2004) Synthesis of naturally occurring o-heterocyclic compounds of biological activity. Pure and applied chemistry 76:1025-1032. doi: 10.1351/pac200476051025

98. Lygin AV, Zernova OV, Hill CB, Kholina NA, Widholm JM, Hartman GL and Lozovaya VV (2013) Glyceollin is an important component of soybean plant defense against Phytophthora sojae and Macrophomina phaseolina. Phytopathology 103:984-994. doi: 10.1094/PHYTO-12-12-0328-R

99. García-Ponce B and Rocha-Sosa M (2000) The octadecanoid pathway is required for pathogen-induced multi-functional acetylCoA carboxylase accumulation in common bean (Phaseolus vulgaris L.). Plant science 157:181-190. doi: 10.1016/S0168-9452(00)002855

100. Andrews S (2010) FastQC: a quality control tool for high throughput sequence data. Available online http://www.bioinformatics.babraham.ac.uk/projects/fastqc.,

101. Bolger AM, Lohse M and Usadel B (2014) Trimmomatic: a flexible trimmer for Illumina sequence data. Bioinformatics 30:21142120. doi: 10.1093/bioinformatics/btu170

102. Grabherr MG, Haas BJ, Yassour M, Levin JZ, Thompson DA, Amit I, Adiconis X, Fan L, Raychowdhury R and Zeng Q (2011) Trinity: reconstructing a full-length transcriptome without a genome from RNA-Seq data. Nature biotechnology 29:644. doi: 10.1038/nbt.1883

103. Langmead B and Salzberg SL (2012) Fast gapped-read alignment with Bowtie 2. Nature methods 9:357-359. doi: 10.1038/nmeth.1923

104. Altschul SF, Gish W, Miller W, Myers EW and Lipman DJ (1990) Basic local alignment search tool. Journal of molecular biology 215:403-410.

105. Kearse M, Moir R, Wilson A, Stones-Havas S, Cheung M, Sturrock S, Buxton S, Cooper A, Markowitz S and Duran C (2012) Geneious Basic: an integrated and extendable desktop software platform for the organization and analysis of sequence data. Bioinformatics 28:1647-1649. doi: 10.1093/bioinformatics/bts199

106. Atallah J, Plachetzki DC, Jasper WC and Johnson BR (2013) The utility of shallow RNA-seq for documenting differential gene expression in genes with high and low levels of expression. PLoS One 8:e84160. doi: 10.1371/journal.pone.0084160 